\title{
Comparison of cerebral blood flow in oral somatic delusion in patients with and without a history of depression: a comparative case series
}

Motoko Watanabe ${ }^{1 *}$, Yojiro Umezaki ${ }^{1}$, Anna Miura', Yukiko Shinohara' ${ }^{1}$ Tatsuya Yoshikawa ${ }^{2}$, Tomomi Sakuma ${ }^{2}$, Chisa Shitano², Ayano Katagiri', Miho Takenoshita' ${ }^{1}$, Akira Toriihara ${ }^{3}$, Akihito Uezato ${ }^{4}$, Toru Nishikawa ${ }^{4}$,

Haruhiko Motomura ${ }^{1}$ and Akira Toyofuku ${ }^{1}$

\begin{abstract}
Background: A significant number of patients visit dental clinics because of unusual oral sensations for which no physical cause can be found. Such patients are recognized as having oral somatic delusion (OSD). OSD may be either primary (monosymptomatic) or secondary to another disease, such as depression or cerebral infarction. Although the presenting complaints of patients with primary and secondary OSD are nearly indistinguishable, symptoms in patients with secondary OSD seem to be resistant to treatment compared with those in patients with primary OSD. Moreover, right dominant cerebral blood flow (CBF) has been reported in patients with primary OSD, but the difference in CBF between patients with primary and secondary OSD remains unclear. The aim of this study was to assess the differences in clinical characteristics and CBF distribution between patients with monosymptomatic OSD (non-depression group) and OSD in conjunction with remitted depression (depression group).
\end{abstract}

Methods: Participants were 27 patients of a psychosomatic dentistry clinic, all diagnosed with OSD. They were categorized into either the non-depression group (17 patients) or the depression group (10 patients) on the basis of assessments by their personal medical providers. CBF was examined using single-photon emission computed tomography.

Results: There was no difference in clinical presentation between the two groups. A significant right dominant asymmetry in the temporal and posterior cerebral regions was observed in both groups. In the central region, a right dominance was seen in the non-depression group, while a left dominance was seen in the depression group. Moreover, the mean regional CBF values for patients in the depression group were significantly lower in several regions (including bilateral callosomarginal, precentral, angular, temporal, posterior cerebral, pericallosal, lenticular nucleus, thalamus, and hippocampus; and right central and cerebellum) than for patients in the non-depression group.

Conclusion: These results suggest that the temporal and posterior cerebral regions are involved in in the pathophysiology of OSD, regardless of depression history, and that widespread CBF reduction is a characteristic of remitted depression.

Keywords: Brain perfusion, Delusional disorder somatic type, Oral somatic delusion, Remitted depression, SPECT, Temporal region

\footnotetext{
* Correspondence: totoompm@tmd.ac.jp

${ }^{1}$ Department of Psychosomatic Dentistry, Graduate School of Medical and Dental Sciences, Tokyo Medical and Dental University, 1-5-45 Yushima, Bunkyo-ku, Tokyo 113-8549, Japan

Full list of author information is available at the end of the article
} 


\section{Background}

A significant number of patients who visit dental clinics report unusual sensations in the oral area (e.g., sticky or slimy saliva, the presence of foreign objects such as sand, bubbles, eggs or metal pieces, and so on), but no corresponding abnormality can be found on physical examination. Such patients are recognized as having oral somatic delusion (OSD), oral paresthesia, or oral cenesthopathy.

Monosymptomatic OSD [1-3] is categorized as a delusional disorder, somatic type (DDST) [4], but it sometimes appears secondary to a psychiatric disorder such as schizophrenia or depression [5,6] or to cerebrovascular disease [7]. Most patients with monosymptomatic OSD first visit a dental clinic because their cenesthopathic symptoms are limited to the oral cavity, convincing them that there is a physical problem in that area. Some patients with OSD are referred to dentists by their psychiatrists because of oral cenesthopathic symptoms that developed while their depression was in remission. Because the chief complaints of patients with primary and secondary OSD are very similar, it is difficult to distinguish between them on the basis of symptoms alone. However, the symptoms of patients with secondary OSD seem to be resistant to treatment compared with those of patients with primary (monosymptomatic) OSD.

Several studies of regional cerebral blood flow (rCBF) in patients with DDST have shown left temporal and left parietal lobe hypoperfusion that normalized as the symptoms improved [8-10]. We also previously reported a case of OSD in which a rightward asymmetry of blood flow in the temporal area disappeared after successful treatment [2]. Furthermore, another of our recent studies demonstrated that the $\mathrm{CBF}$ in patients with OSD had a right > left asymmetry in the frontal and temporal regions compared with the CBF of control patients [3]. Thus, a rightward asymmetry, especially in the temporal area, may be associated with the development of cenesthopathy.

In the current study, we hypothesized that the clinical features and the CBF distribution patterns in secondary OSD, especially when it appears in the remitted period of depression, are different from those in primary (monosymptomatic) OSD.

With the aim of clarifying the differences between primary (monosymptomatic) OSD and secondary OSD associated with the remitted period of depression, we investigated the clinical characteristics and the CBF distributions using single photon emission computed tomography (SPECT).

\section{Methods}

This study involved 27 patients with OSD who visited the psychosomatic dentistry clinic of Tokyo Medical and
Dental University dental hospital in Tokyo, Japan. All of the subjects provided written informed consent. The exclusion criteria were the presence of a delusion or hallucination involving a body part other than the oral region, abnormalities in magnetic resonance imaging findings, a low Revised Hasegawa Dementia Scale (HDS-R) score $(<25)$ to exclude dementia, and the presence of other neurological diseases, such as Parkinson's disease. Because of previous reports that pain causes changes in the CBF [11-13], subjects with pain in their oral cavity or any other body parts were also excluded.

Based on the results of patient interviews and assessments by their attending doctors (including psychiatrists, family physicians and other medical specialists), the subjects were grouped as follows: non-depression group (no history of psychiatric disorders) and depression group (oral symptoms appeared during a remission period of a major depressive disorder). For the subjects in the depression group, all the subjects' depressive states were assessed as "remitted" or "very much improved" by their psychiatrists.

The depressive state of each subject was assessed at the time of the first examination using the Zung SelfRating Depression Scale (SDS). All subjects were righthanded except subject No. 11.

\section{Ethics statement}

This study was conducted with the approval of the Ethical Committee of Tokyo Medical and Dental University (no. 356).

\section{Demographic data}

The demographic data for all subjects are listed in Tables 1 and 2. The non-depression group consisted of 17 subjects (15 women, 2 men) with no history of psychiatric disorders; the mean \pm standard deviation (SD) age was $67.65 \pm$ 10.33 years (range, 50-83 years). The depression group consisted of 10 subjects (7 women, 3 men) who developed OSD during a remission period of depression; the mean \pm SD age was $67.60 \pm 6.59$ years (range, $57-78$ years).

\section{Brain perfusion SPECT}

SPECT imaging was performed with the subjects resting and supine, with eyes closed and in quiet surroundings after injection of a bolus of $600 \mathrm{MBq}$ of Tc-99 m ethylcysteinate dimer $\left({ }^{99 \mathrm{~m}} \mathrm{Tc}-\mathrm{ECD}\right)$ via the right brachial vein.

First, the passage from the heart to the brain was monitored using a rectangular large-field dual-head gamma camera (E.CAM Signature; Toshiba, Tokyo, Japan) equipped with low-energy high-resolution parallel-hole collimators. Data acquisition consisted of a sequence of 100 frames at a rate of $1 \mathrm{~s} /$ frame using a $128 \times 128$ matrix. Next, SPECT images were obtained using the same gamma camera equipped with fan-beam collimators. The 
Table 1 Profiles of subjects in the non-depression group

\begin{tabular}{|c|c|c|c|c|c|c|c|}
\hline No. & $\begin{array}{l}\text { age } \\
\text { sex }\end{array}$ & $\begin{array}{l}\text { Duration } \\
\text { of illness } \\
\text { (months) }\end{array}$ & Complants & $\begin{array}{l}\text { Onset } \\
\text { opportunities }\end{array}$ & $\begin{array}{l}\text { Antipsychotics } \\
\text { beeing taken at time } \\
\text { of first examination }\end{array}$ & $\begin{array}{l}\text { Antipsychotics beeing } \\
\text { taken at the time of } \\
\text { SPECT examination }\end{array}$ & $\begin{array}{l}\text { SDS at } \\
\text { time of first } \\
\text { examination }\end{array}$ \\
\hline 1 & $75 \mathrm{~F}$ & 20 & too much saliva & extraction & $\begin{array}{l}\text { sulpiride } 50 \mathrm{mg} \text {, } \\
\text { zolpidem } 10 \mathrm{mg}\end{array}$ & $\begin{array}{l}\text { aripiprazole } 1.5 \mathrm{mg}, \\
\text { sulpiride } 50 \mathrm{mg}, \\
\text { zolpidem } 10 \mathrm{mg}\end{array}$ & 43 \\
\hline 2 & $72 \mathrm{~F}$ & 9 & $\begin{array}{l}\text { numerous "balloons" in a hole } \\
\text { in the palate }\end{array}$ & none & triazolam 0.125 mg & $\begin{array}{l}\text { aripiprazole } 1.5 \mathrm{mg}, \\
\text { triazolam } 0.125 \mathrm{mg}, \\
\text { zolpidem } 5 \mathrm{mg}\end{array}$ & 23 \\
\hline 3 & $50 \mathrm{~F}$ & 13 & $\begin{array}{l}\text { bubbles and a filmy substance } \\
\text { exuding from teeth }\end{array}$ & none & $\begin{array}{l}\text { sulpiride } 150 \text { mg, } \\
\text { clotiazepam } 5 \text { mg, } \\
\text { lorazepam } 0.5 \mathrm{mg}\end{array}$ & $\begin{array}{l}\text { sertraline } 25 \text { mg, } \\
\text { milnacipran } 100 \text { mg, } \\
\text { lorazepam } 1.5 \mathrm{mg}\end{array}$ & 33 \\
\hline 4 & $80 \mathrm{~F}$ & 10 & $\begin{array}{l}\text { presence of something like } \\
\text { liquid exuding from her mandibular }\end{array}$ & $\begin{array}{l}\text { reflux } \\
\text { esophagitis }\end{array}$ & - & $\begin{array}{l}\text { perospirone } 12 \mathrm{mg} \text {, } \\
\text { sertraline } 25 \mathrm{mg}\end{array}$ & 44 \\
\hline 5 & $64 M$ & 18 & $\begin{array}{l}\text { presence of something like plastic ties } \\
\text { in the space between teeth and bone }\end{array}$ & $\begin{array}{l}\text { prosthesis } \\
\text { (denture) }\end{array}$ & $\begin{array}{l}\text { flunitrazepam } 4 \text { mg, } \\
\text { nitrazepam } 5 \text { mg }\end{array}$ & $\begin{array}{l}\text { sertraline } 75 \text { mg, } \\
\text { mirtazapine } 30 \text { mg, } \\
\text { ethyl loflazepate } 2 \text { mg }\end{array}$ & 24 \\
\hline 6 & $76 \mathrm{~F}$ & 9 & sticky, glue-like substance in mouth & none & - & aripiprazole $3 \mathrm{mg}$ & 29 \\
\hline 7 & $83 \mathrm{~F}$ & 26 & $\begin{array}{l}\text { garbage exuding from beneath } \\
\text { dentures; sticky and sandy mouth }\end{array}$ & $\begin{array}{l}\text { prosthesis } \\
\text { (denture) }\end{array}$ & - & aripiprazole 1.5 mg & 56 \\
\hline 8 & $81 \mathrm{~F}$ & 16 & sticky mouth and dry lips & none & $\begin{array}{l}\text { clonazepam } 1.5 \mathrm{mg} \text {, } \\
\text { zopiclone } 7.5 \mathrm{mg}\end{array}$ & $\begin{array}{l}\text { mirtazapine } 7.5 \mathrm{mg} \text {, } \\
\text { zopiclone } 7.5 \mathrm{mg} \\
\text { clonazepam } 1.5 \mathrm{mg}\end{array}$ & 44 \\
\hline 9 & $70 \mathrm{~F}$ & 56 & $\begin{array}{l}\text { sticky mouth; bitter and salty substances } \\
\text { exuding from mouth }\end{array}$ & $\begin{array}{l}\text { prosthesis } \\
\text { (denture) }\end{array}$ & etizolam $1.0 \mathrm{mg}$ & mirtazapine 15 mg & 64 \\
\hline 10 & $60 \mathrm{~F}$ & 21 & $\begin{array}{l}\text { sticky mouth; sour and bitter taste; bubbles } \\
\text { and slimy substances persists around throat }\end{array}$ & none & etizolam $1.0 \mathrm{mg}$ & $\begin{array}{l}\text { sertraline } 25 \text { mg, } \\
\text { mirtazapine } 15 \text { mg, } \\
\text { etizolam } 0.5 \text { mg }\end{array}$ & 64 \\
\hline 11 & $71 \mathrm{M}$ & 45 & lint exuding from interdentium & none & zolpidem 10 mg & $\begin{array}{l}\text { mianserine } 10 \text { mg, } \\
\text { bromazepam } 4 \text { mg, } \\
\text { zolpidem } 10 \text { mg }\end{array}$ & 38 \\
\hline 12 & $70 \mathrm{~F}$ & 23 & $\begin{array}{l}\text { movement of a dental implant and } \\
\text { balls in her mouth; pins coming } \\
\text { out through the night; sticky saliva }\end{array}$ & $\begin{array}{l}\text { prosthesis } \\
\text { (denture) }\end{array}$ & - & amitriptyline 30 mg & 74 \\
\hline 13 & $72 \mathrm{~F}$ & 8 & $\begin{array}{l}\text { movement of a dental implant and } \\
\text { balls in her mouth; pins coming out } \\
\text { through the night; sticky saliva }\end{array}$ & $\begin{array}{l}\text { prosthesis } \\
\text { (denture) }\end{array}$ & - & ethyl loflazepate 1.5 mg & 34 \\
\hline 14 & $61 \mathrm{~F}$ & 20 & sticky mouth and too much saliva & prosthesis & - & - & 50 \\
\hline 15 & $55 \mathrm{~F}$ & 22 & dental bridge feels too tight & extraction & - & aripiprazole $1 \mathrm{mg}$ & 47 \\
\hline 16 & $50 \mathrm{~F}$ & 10 & sticky mouth and salty-sweet taste & none & triazolam $0.125 \mathrm{mg}$ & aripiprazole $1 \mathrm{mg}$ & 46 \\
\hline 17 & $60 \mathrm{~F}$ & 54 & sticy mouth and salty saliva & prosthesis & - & - & 33 \\
\hline
\end{tabular}

SPECT: single-photon emission tomography.

SDS: Zung Self-Rating Depression Scale.

energy window was set at $140 \mathrm{keV} \pm 15 \%$, and 45 step-and shoot images were obtained throughout 180 degrees of rotation $(128 \times 128$ matrix, $1.72 \mathrm{~mm} /$ pixel $)$ with an acquisition time of $30 \mathrm{~s} / \mathrm{step}$. All the images were reconstructed using the ordered subset expectation maximization method and were smoothed three-dimensionally using a Butterworth filter. The Chang method was used to correct for gamma ray attenuation.

\section{Data analysis}

For the regional $\mathrm{CBF}$ (rCBF) quantification, the Patlak plot method [14,15] was applied to the ${ }^{99 \mathrm{~m}} \mathrm{Tc}-\mathrm{ECD}$ cerebral blood perfusion SPECT images to measure the mean CBF (mCBF) of bilateral cerebral hemispheres. Quantitative flow-mapping images were then obtained from the qualitative cerebral perfusion SPECT images using the Patlak plot graphical analysis and Lassen's correction $[16,17]$.

The rCBF quantification was performed using a threedimensional stereotactic regions of interest template (3DSRT) program $[18,19]$. 3DSRT is a fully automated rCBF quantification program that can be used to examine a total of 636 regions of interest (ROIs). These 636 ROIs are categorized into 12 brain segments on the 
Table 2 Profiles of subjects in the depression group

\begin{tabular}{|c|c|c|c|c|c|c|c|c|c|}
\hline No. & $\begin{array}{l}\text { age } \\
\text { sex }\end{array}$ & $\begin{array}{l}\text { Duration } \\
\text { of illness } \\
\text { (months) }\end{array}$ & $\begin{array}{l}\text { Duration between } \\
\text { onset of depression } \\
\text { and onset of oral } \\
\text { cenesthopathy } \\
\text { (years) }\end{array}$ & Complants & $\begin{array}{l}\text { Onset } \\
\text { opportunities }\end{array}$ & $\begin{array}{l}\text { Antipsychotics beeing } \\
\text { taken at time of first } \\
\text { examination }\end{array}$ & $\begin{array}{l}\text { Antipsychotics beeing } \\
\text { taken at the time of } \\
\text { SPECT examination }\end{array}$ & $\begin{array}{l}\text { SDS at time } \\
\text { of first } \\
\text { examination }\end{array}$ & $\begin{array}{l}\text { Depressive state } \\
\text { at onset of oral } \\
\text { cenesthopathy }\end{array}$ \\
\hline 18 & $57 \mathrm{~F}$ & 16 & 1 & $\begin{array}{l}\text { too much saliva; feels like } \\
\text { mouth is vacuumed. }\end{array}$ & $\begin{array}{l}\text { psychological } \\
\text { stress }\end{array}$ & $\begin{array}{l}\text { amitriptyline } 55 \text { mg, } \\
\text { flunitrazepam } 2 \text { mg }\end{array}$ & $\begin{array}{l}\text { mirtazapine } 15 \mathrm{mg}, \\
\text { flunitrazepam } 2 \mathrm{mg}\end{array}$ & 34 & remission \\
\hline 19 & $70 \mathrm{~F}$ & 81 & 15 & $\begin{array}{l}\text { tight gums from wich } \\
\text { salive is squeezing out }\end{array}$ & $\begin{array}{l}\text { psychological } \\
\text { stress }\end{array}$ & $\begin{array}{l}\text { alprazolam } 0.4 \text { mg, } \\
\text { brotizolam } 0.25 \mathrm{mg} \text {, } \\
\text { amoxapine } 20 \mathrm{mg}\end{array}$ & aripiprazole $1.5 \mathrm{mg}$ & 29 & $\begin{array}{l}\text { very much } \\
\text { improved }\end{array}$ \\
\hline 20 & $68 \mathrm{~F}$ & 18 & 7 & $\begin{array}{l}\text { gum-like sticky substance } \\
\text { persists over thin, hard } \\
\text { substance on teeth }\end{array}$ & stomatitis & $\begin{array}{l}\text { haloperidole } 0.75 \mathrm{mg} \text {, } \\
\text { amitriptyline } 100 \mathrm{mg} \text {, } \\
\text { brotizolam } 0.5 \mathrm{mg} \text {, } \\
\text { clotiazepam } 10 \mathrm{mg}\end{array}$ & $\begin{array}{l}\text { haloperidole } 0.75 \mathrm{mg} \text {, } \\
\text { aripiprazole } 6 \mathrm{mg} \text {, } \\
\text { amitriptyline } 85 \mathrm{mg} \text {, } \\
\text { brotizolam } 0.25 \mathrm{mg} \text {, } \\
\text { clonazepam } 1.5 \mathrm{mg}\end{array}$ & 36 & $\begin{array}{l}\text { very much } \\
\text { improved }\end{array}$ \\
\hline 21 & $69 \mathrm{~F}$ & 13 & 7 & greasy saliva coating teeth & none & paroxetine $20 \mathrm{mg}$ & $\begin{array}{l}\text { paroxetine } 20 \mathrm{mg} \text {, } \\
\text { brotizolam } 0.25 \mathrm{mg} \text {, } \\
\text { trihexyphenidyl } 4 \text { mg }\end{array}$ & 41 & $\begin{array}{l}\text { very much } \\
\text { improved } \\
\text { and stabilized }\end{array}$ \\
\hline 22 & $78 \mathrm{~F}$ & 50 & 7 & $\begin{array}{l}\text { slimy liquid exudingfrom } \\
\text { throat }\end{array}$ & none & $\begin{array}{l}\text { paroxetine } 15 \mathrm{mg}, \\
\text { alprazolam } 1.2 \mathrm{mg}, \\
\text { brotizolam } 0.25 \mathrm{mg}, \\
\text { lormetazepam } 1 \mathrm{mg}, \\
\text { flunitrazepam } 1 \mathrm{mg}\end{array}$ & mianserin $10 \mathrm{mg}$ & 50 & remission \\
\hline 23 & $74 \mathrm{~F}$ & 3 & 1 & $\begin{array}{l}\text { tasteless; substance resembling } \\
\text { frog eggs or pins persists over } \\
\text { tongue and membranes or fibers } \\
\text { present on labial mucosa; } \\
\text { sandy mouth }\end{array}$ & none & sertraline $50 \mathrm{mg}$ & sertraline $50 \mathrm{mg}$ & 49 & $\begin{array}{l}\text { very much } \\
\text { improved }\end{array}$ \\
\hline 24 & $70 \mathrm{M}$ & 60 & 3 & $\begin{array}{l}\text { dry mouth; space in palate is too } \\
\text { full causing a chocking feeling }\end{array}$ & dental implants & $\begin{array}{l}\text { triazolam } 0.05 \mathrm{mg} \text {, } \\
\text { etizolam } 0.5 \mathrm{mg}\end{array}$ & etizolam $0.25 \mathrm{mg}$ & 36 & $\begin{array}{l}\text { very much } \\
\text { improved } \\
\text { and stabilized }\end{array}$ \\
\hline 25 & $58 \mathrm{M}$ & 34 & 6 & $\begin{array}{l}\text { metal substance extrudingt } \\
\text { from teeth; too much saliva }\end{array}$ & dental implants & $\begin{array}{l}\text { clomipramine } 100 \text { mg, } \\
\text { mirtazapine } 15 \mathrm{mg} \text {, } \\
\text { ethyl flozepate } 1 \mathrm{mg} \text {, } \\
\text { etizolam } 0.5 \mathrm{mg} \text {, }\end{array}$ & $\begin{array}{l}\text { aripiprazole } 3 \text { mg, } \\
\text { clomipramine } 100 \text { mg, } \\
\text { mirtazapine } 15 \text { mg, } \\
\text { etizolam } 0.5 \mathrm{mg}\end{array}$ & 30 & almost remission \\
\hline 26 & $63 \mathrm{~F}$ & 16 & 2 & bubbly saliva & $\begin{array}{l}\text { psychological } \\
\text { stress }\end{array}$ & $\begin{array}{l}\text { olanzapine } 2.5 \mathrm{mg} \text {, } \\
\text { fluvoxamine } 75 \mathrm{mg} \text {, } \\
\text { zopidem } 10 \mathrm{mg}, \\
\text { brotizolam } 0.5 \mathrm{mg}, \\
\text { lormetazepam } 2 \mathrm{mg}\end{array}$ & $\begin{array}{l}\text { aripirazole } 3 \text { mg, } \\
\text { fluvoxamine } 75 \text { mg, } \\
\text { ethyl loflazepate } 2 \text { mg, } \\
\text { zolpidem } 10 \text { mg, } \\
\text { brotizolam } 0.5 \text { mg, } \\
\text { lormetazepam } 2 \text { mg, } \\
\text { biperiden } 1 \mathrm{mg}\end{array}$ & 44 & $\begin{array}{l}\text { very much } \\
\text { improved } \\
\text { and stabilized }\end{array}$ \\
\hline 27 & $69 \mathrm{M}$ & 62 & 18 & sticky mouth & prosthesis & $\begin{array}{l}\text { zopiclone } 7.5 \mathrm{mg} \\
\text { cloxazolam } 3 \mathrm{mg}\end{array}$ & $\begin{array}{l}\text { aripiprazole } 1.5 \text { mg, } \\
\text { mirtazapine } 7.5 \text { mg }\end{array}$ & 40 & remission \\
\hline
\end{tabular}

SPECT: single-photon emission tomography.

SDS: Zung Self-Rating Depression Scale. 
3DSRT template: callosomarginal, precentral, central, parietal, angular, temporal, posterior cerebral, pericallosal, lenticular nucleus, thalamus, hippocampal, and cerebellar segments. The blood flow to each ROI was quantified in $\mathrm{mL} / 100 \mathrm{~g} / \mathrm{min}$.

For the analysis, the rCBF values obtained from the 3DSRT data and $\mathrm{mCBF}$ values obtained from the Patlak Plot method were used. As an index of brain perfusion asymmetry, the right to right + left ratio $[R /(\mathrm{R}+\mathrm{L})$ ratio] was calculated for the 12 brain segments in each subject.

The $R /(R+L)$ ratio equaled the rCBF values for the target segment on the right side divided by the sum of the $\mathrm{rCBF}$ values for the corresponding segments on the right and left sides.

The mean $\mathrm{rCBF}$ values and the mean $\mathrm{R} /(\mathrm{R}+\mathrm{L})$ ratios for each brain segment and the $\mathrm{mCBF}$ values for global and for right and left hemispheres were calculated separately for the non-depression and the depression group. The results were expressed as the mean $\pm \mathrm{SD}$.

\section{Statistical analysis}

PASW 17.0 software (IBM, Chicago, IL, USA) was used to perform the Mann-Whitney $U$ test and the Pearson's $X^{2}$ test. All the tests were two-tailed, and $P$ values $<0.05$ were considered statistically significant.

\section{Results}

\section{Clinical features of patients in non-depression and depression groups}

Tables 1 and 2 show the demographic and clinical data of the OSD patients involved in the present study. No significant differences in age $(P=0.639)$ or $\operatorname{sex}(P=$ 0.239 ) were observed between the non-depression and the depression groups. In our previous report [3], the subjects were also predominantly female (6 women, 2 men), but the mean \pm SD age was $75.9 \pm 6.0$ years, which is older than the subjects in the present study.

As shown in Tables 1 and 2, the chief complaints in both groups were similar: "sticky or slimy saliva", "foreign body sensation", "bitter or sour taste", or "something resembling bubbles, pieces of metal, or plastic". The duration of illness in the depression group was $27.14 \pm 20.52$ months (range, 3-81 months), which was longer than that in the non-depression group $(22.35 \pm$ 15.18 months; range, 8-56 months). However, the difference was not significant $(P=0.309)$. Despite the long duration of symptoms, all the subjects continued to socialize. In the depression group, the mean time from onset of depression to onset of OSD varied (6.70 \pm 5.76 years; range, 1-18 years), but all of the subjects were in the remission period of depression when the OSD appeared, according to the assessments made by their psychiatrists. In the depression group, the medications that were being taken at the time of the first examination were mainly anxiolytics or hypnotics, and some patients were not taking any antidepressant at all. Regarding the SDS score, the mean score in the nondepression group $(43.9 \pm 14.4)$ was somewhat higher than that in the depression group (38.9 \pm 7.26$)$, but the difference was not statistically significant $(P=0.245)$. No apparent difference was observed in any clinical characteristic categories between the non-depression and depression groups.

\section{Difference in rCBF between non-depression and depression groups}

Table 3 shows the mean rCBF values for the 24 segments in each of the groups. In the non-depression group, a right dominant asymmetry was observed for many segments, especially the temporal, posterior cerebral, and cerebellum (where significant differences were observed). In the depression group, a significant right dominant asymmetry was observed in the temporal and posterior cerebral. Furthermore, in the depression group, the central region showed a significant left dominant asymmetry. We examined and compared the $\mathrm{R} /(\mathrm{R}+\mathrm{L})$ ratio in each region for both groups (Figure 1). A right dominant asymmetry was observed in many regions in both the non-depression and depression groups. However, a significant difference between the non-depression and depression groups was observed only for the central region, with a right dominant asymmetry observed in the non-depression group and a left dominant asymmetry observed in the depression group.

Figure 2 shows the difference in the mean $\mathrm{rCBF}$ values between the non-depression and depression groups. Analysis of each segment revealed that the mean $\mathrm{rCBF}$ values in the depression group were significantly lower than those of the non-depression group in the bilateral callosomarginal and precentral; right central; bilateral angular, temporal, posterior cerebral, pericallosal, lenticular nucleus, thalamus, and hippocampus; and right cerebellum. Moreover, because the rCBF patterns in both groups were similar, these reductions were not partial but were total and even. To confirm these global $\mathrm{CBF}$ reductions in the depression group, the $\mathrm{mCBF}$ values measured by the Patlak Plot method also compared the two groups. The mCBF values in the depression group were significantly lower in the global $(P=$ $0.0045)$ and the right $(P=0.0014)$ and left $(P=0.0011)$ hemispheres than those in the non-depression group (Figure 3).

\section{Effects of medications on mCBF values}

As listed in Table 1, 15/17 patients in the non-depression group and 10/10 patients in the depression group were taking psychotropics (antipsychotics, antidepressants, or anxiolytics) or hypnotics at the time of SPECT 
Table 3 Mean rCBF values for 24 segments in the non-depression and depression groups

Right hemisphere Left hemisphere $P$ value

non-depression group

\begin{tabular}{|c|c|c|c|}
\hline callosomarginal & $43.9 \pm 3.82$ & $43.56 \pm 4.19$ & 0.156 \\
\hline precentral & $46.41 \pm 4.18$ & $45.44 \pm 4.62$ & 0.114 \\
\hline central & $44.61 \pm 3.54$ & $43.98 \pm 3.99$ & 0.198 \\
\hline parietal & $44.28 \pm 4.03$ & $42.94 \pm 4.07$ & 0.056 \\
\hline angular & $46.92 \pm 4.96$ & $45.54 \pm 3.90$ & 0.097 \\
\hline temporal & $43.74 \pm 3.34$ & $41.99 \pm 3.44$ & $0.012^{*}$ \\
\hline posteriorcerebral & $48.34 \pm 3.85$ & $47.41 \pm 3.87$ & $0.042^{*}$ \\
\hline pericallosal & $46.74 \pm 4.16$ & $46.43 \pm 4.52$ & 0.115 \\
\hline lenticular nucleus & $50.13 \pm 4.58$ & $49.39 \pm 4.54$ & 0.260 \\
\hline thalamus & $46.94 \pm 5.33$ & $46.15 \pm 4.66$ & 0.218 \\
\hline hippocampus & $37.74 \pm 4.02$ & $37.81 \pm 4.31$ & 0.876 \\
\hline cerebellum & $55.67 \pm 5.61$ & $54.42 \pm 6.34$ & $0.018^{*}$ \\
\hline \multicolumn{4}{|l|}{ depression group } \\
\hline callosomarginal & $39.19 \pm 4.33$ & $39.28 \pm 4.40$ & 0.564 \\
\hline precentral & $41.78 \pm 5.22$ & $41.12 \pm 4.39$ & 0.344 \\
\hline central & $40.71 \pm 4.42$ & $41.55 \pm 4.03$ & $0.030^{*}$ \\
\hline parietal & $39.84 \pm 5.14$ & $39.27 \pm 4.49$ & 0.366 \\
\hline angular & $40.71 \pm 4.30$ & $40.56 \pm 4.61$ & 0.887 \\
\hline temporal & $38.26 \pm 3.30$ & $36.96 \pm 2.83$ & $0.027^{*}$ \\
\hline posteriorcerebral & $44.50 \pm 3.71$ & $43.80 \pm 3.46$ & $0.016^{*}$ \\
\hline pericallosal & $42.14 \pm 4.68$ & $41.93 \pm 4.30$ & 0.355 \\
\hline lenticular nucleus & $45.00 \pm 3.12$ & $44.63 \pm 2.74$ & 0.229 \\
\hline thalamus & $41.03 \pm 4.35$ & $39.58 \pm 4.39$ & 0.186 \\
\hline hippocampus & $33.82 \pm 2.51$ & $33.56 \pm 2.43$ & 0.662 \\
\hline cerebellum & $51.11 \pm 4.21$ & $50.35 \pm 4.72$ & 0.142 \\
\hline
\end{tabular}

*; $P<0.05$

In the non-depression group, significant right dominant asymmetries were observed in the temporal, posterior cerebral, and cerebellum. In the depression group, a significant left dominant asymmetry was observed in the central, and significant right dominant asymmetries were observed in the temporal and posterior cerebral.

examination. Since the doses and types of medications vary widely, this factor is difficult to standardize. We concentrated on the use of antidepressants, which were taken by the largest number of subjects, and standardized the data using an imipramine equivalent [20] (Table 4). No significant difference in the imipramine equivalent dose was observed between the non-depression and depression groups $(P=0.155)$. The number of patients taking antidepressants was $8 / 17$ in the non-depression group and 8/10 in the depression group. Focusing on only the patients who were taking antidepressants, the $\mathrm{mCBF}$ value in the depression group was significantly lower than that in the non-depression group (8 patients in each group; global $P=0.050$; left hemisphere $P=0.038$, right hemisphere $P=0.021$ ), with no significant difference in the imipramine equivalent doses $(P=0.959)$. Within the non-depression group, the mCBF value in the 8 patients taking antidepressants was slightly lower than that in the 9 patients who were not taking antidepressants, although the difference was not significant (global $P=0.167$; left hemisphere $P=0.236$; right hemisphere $P=0.321$ ).

\section{Discussion}

The present study had two principal findings. First, no apparent clinical symptomatic difference was observed between the pure and depression groups, and a right dominant asymmetry was observed in the temporal and posterior cerebral in both groups. On the other hand, in the central, a significant difference was observed between both groups: a left dominant asymmetry was observed in the depression group, while a right dominant asymmetry was observed in the pure group.

Second, the mean rCBF values in the depression group were significantly lower than those in the pure group in many regions. Moreover, in the depression group, the mean $\mathrm{mCBF}$ values in the global, and the right and left hemispheres were also significantly lower than those in the pure group.

\section{Right dominant asymmetry in OSD}

A right dominant asymmetry was observed in the nondepression group, but the asymmetry was not as prominent as that in our previous report [3]. The reason for this difference might have been the different characteristics and number of subjects in the two studies. Because the results of our previous study suggested that OSD has various subtypes, patients with cenesthopathic symptoms in other body parts or who were experiencing pain were excluded from the present study. Such careful screening to select more homogeneous OSD might have contributed to the difference in the results between the present study and our previous study. The difference in the mean age might also have contributed to the difference in the degree of asymmetry. However, a significant right dominant asymmetry in the temporal region was common to both the present and our previous studies. Our previous case report [2] showed a right dominant asymmetry in the temporal region that became less marked after an improvement in the symptoms of OSD. Therefore, the temporal region might play an important role in the pathophysiology of OSD. Moreover, since the right dominant asymmetry in the temporal region was found in not only the non-depression group but also in the depression group, the temporal region might be involved in the pathophysiology of OSD regardless of the history of depression. On the other hand, no previous report about the right dominant asymmetry in the posterior cerebral was found. Based on the results of this study, the posterior cerebral as well as the temporal 


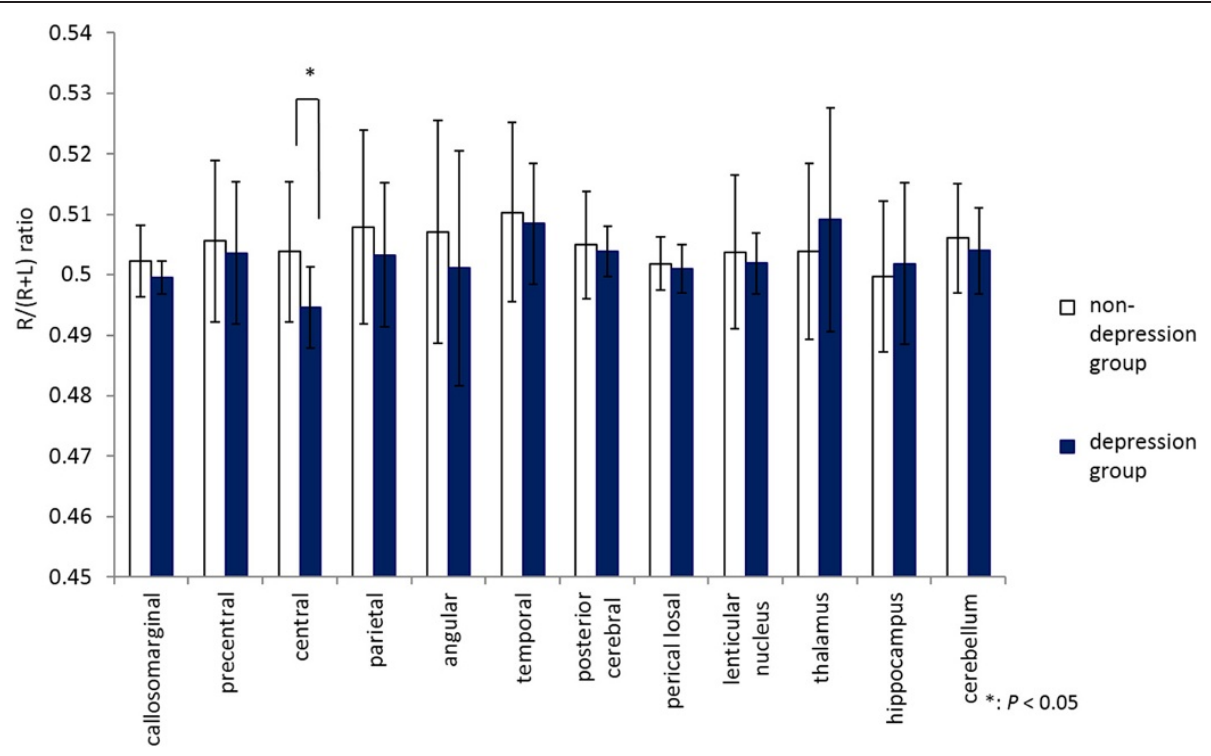

Figure $1 \mathrm{Mean} R /(\mathrm{R}+\mathrm{L})$ ratio for each segment. A significant difference was observed in the central: a right dominant asymmetry was observed in the non-depression group, and a left dominant asymmetry was observed in the depression group.

region might be involved in the pathophysiology of OSD; however, further studies are necessary to confirm this theory.

In the central, a significant difference was observed between the non-depression and depression groups: right dominance was observed in the non-depression group, while left dominance was observed in the depression group. This result suggests that the central region, including the central sulcus, which is well known as a somatosensory and motor area, is involved in the pathophysiology of OSD. Further investigations are expected.

\section{Global reduction in CBF in the depression group}

Mean rCBF values of the depression group were significantly lower than those of the non-depression group in several regions, and the $\mathrm{mCBF}$ values were also significantly lower in the global and the right and left hemispheres.

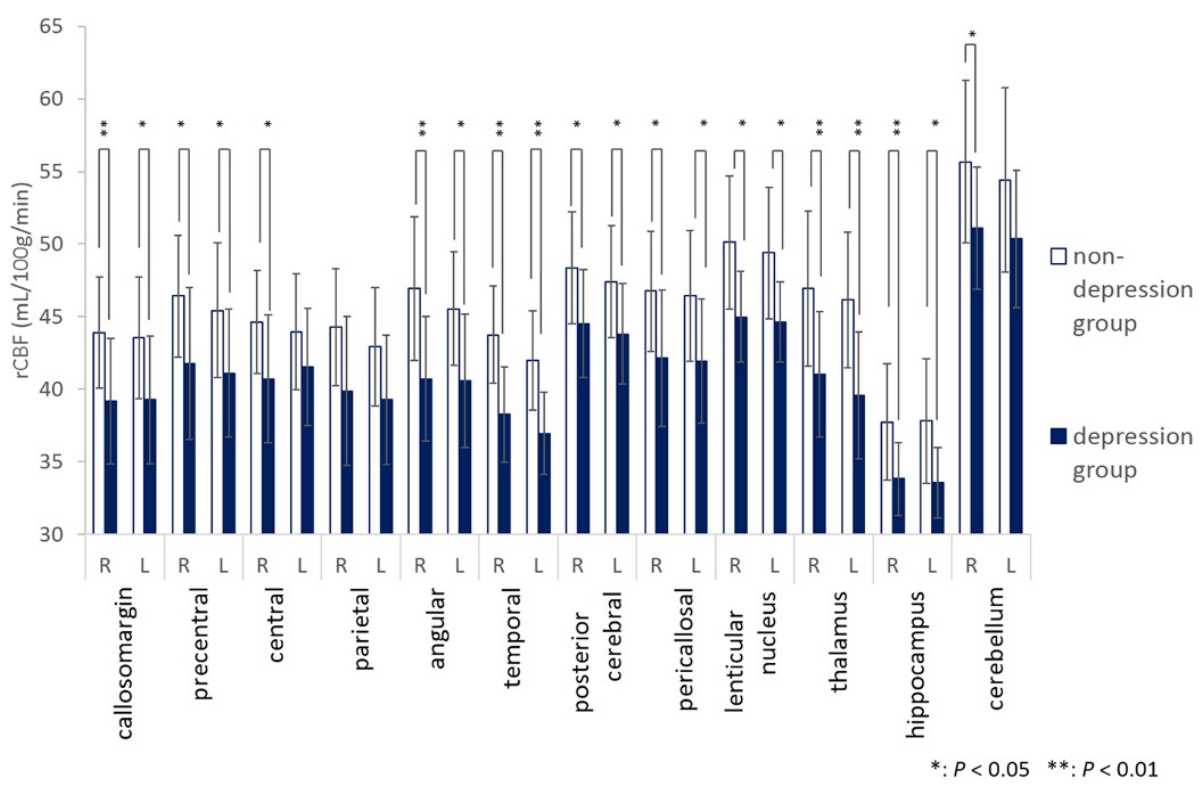

Figure 2 Mean regional cerebral blood flow values for $\mathbf{2 4}$ segments in each group. The mean rCBF values in the depression group were significantly lower in all segments except the left central, bilateral parietal, and cerebellum, compared with the values in the non-depression group. 


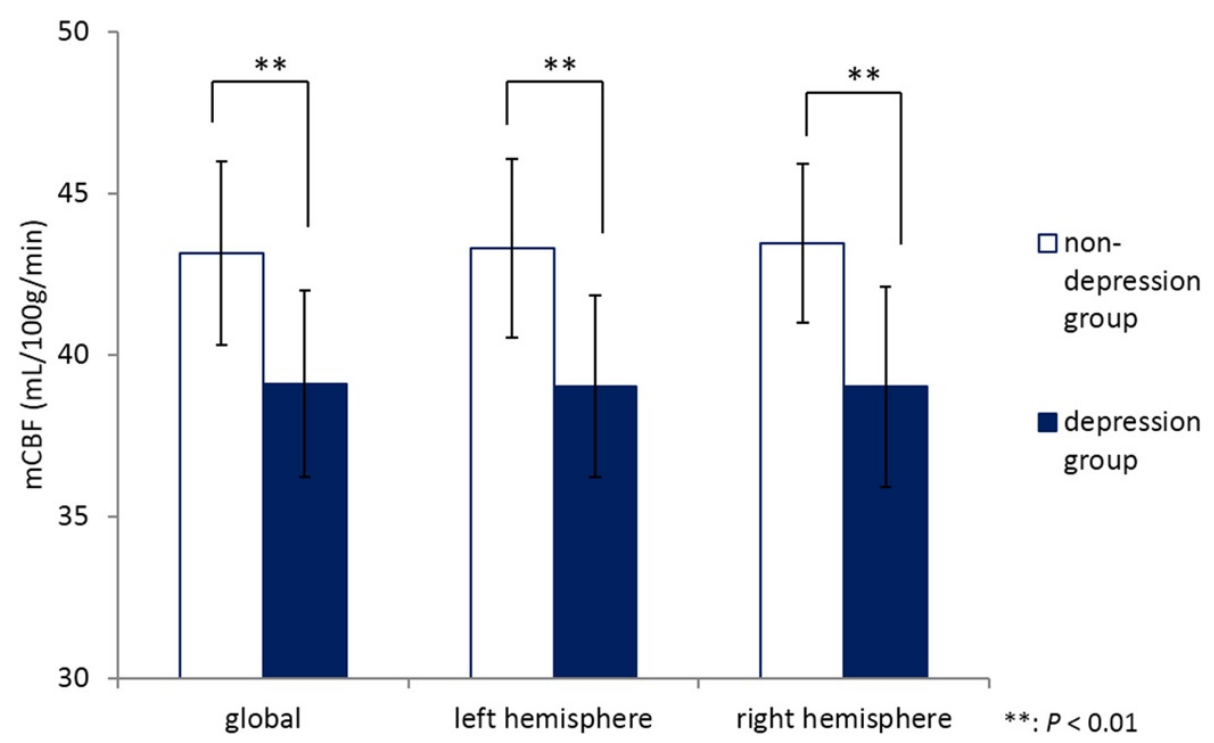

Figure 3 Mean regional cerebral blood flow values for global and the left and right hemispheres. All the $\mathrm{mCBF}$ values in the depression group were significantly lower than those in the non-depression group.

Whether the non-depression group or the depression group showed abnormal perfusion is unknown, since they were not compared with non-OSD controls. However, in our previous study [3], the absolute CBF values in subjects with OSD (8 cases) were somewhat higher than those of subjects without OSD (8 cases), although the difference was not significant. Therefore, a global CBF decrease in the depression group may be a more likely explanation for the differences than a CBF increase in the non-depression group.

The reasons for these CBF reductions should be carefully examined from several aspects.

\section{Effects of medications on mCBF values}

The first reason that should be considered is the effect of medications. Some medications, including antidepressants, antipsychotics, anxiolytics, and hypnotics, reportedly decrease or increase the CBF [21-23].
However, the results in this study suggest that the effect of medications is not sufficient to explain the CBF reduction observed in widespread regions in the depression group, even when the data is partially corrected for medication use.

\section{Effects of depression itself on the mCBF values}

Another reason that should be considered is the effect of depression itself. The theory that CBF may be widely decreased by of comorbid depression is fascinating. There are many previous studies of CBF in depressive patients. Some reported a total reduction [24-26], which is similar to the results of the present study, but others reported regional reductions in the frontal, temporal, or parietal regions [27-29]. Because of such varied and inconsistent results, CBF changes in depression are still unclear. On the other hand, remitted depression has also been studied with regard to several factors including

Table 4 Mean cerebral blood flow (mCBF) values and mean imipramine equivalent doses

\begin{tabular}{|c|c|c|c|c|c|}
\hline & & \multirow{2}{*}{$\begin{array}{l}\text { Mean of } \\
\text { imipramine } \\
\text { equivalent dose }\end{array}$} & \multicolumn{3}{|l|}{ mCBF values } \\
\hline & & & Whole brain & Left hemisphere & Right hemisphere \\
\hline \multirow[t]{3}{*}{ non-depression group } & total $(n=17)$ & $38.53 \pm 65.57$ & $43.15 \pm 2.85$ & $43.31 \pm 2.78$ & $43.45 \pm 2.46$ \\
\hline & taken antidepressants $(\mathrm{n}=8)$ & $81.88 \pm 75.97$ & $42.43 \pm 3.59$ & $42.60 \pm 3.51$ & $42.91 \pm 3.19$ \\
\hline & no antidepressants ( $\mathrm{n}=9$ ) & 0 & $43.79 \pm 2.00$ & $43.93 \pm 1.93$ & $43.93 \pm 1.64$ \\
\hline \multirow[t]{3}{*}{ depression group } & total $(n=10)$ & $58.50 \pm 51.91$ & $39.10 \pm 2.89$ & $39.03 \pm 2.82$ & $39.02 \pm 3.10$ \\
\hline & taken antidepressants $(\mathrm{n}=8)$ & $73.13 \pm 47.35$ & $38.71 \pm 3.03$ & $38.70 \pm 2.91$ & $38.44 \pm 3.21$ \\
\hline & no antidepressants $(\mathrm{n}=2)$ & 0 & $40.65 \pm 2.19$ & $40.35 \pm 2.76$ & $41.35 \pm 0.78$ \\
\hline
\end{tabular}

No difference in the imipramine equivalent doses was observed between the non-depression and depression groups. No difference in the mCBF values was observed between subjects taking and not taking antidepressants. However, focusing on only the patients who took antidepressants, the mCBF value in the depression group was significantly lower than that in the non-depression group. 
$\mathrm{CBF}$, and various differences between subjects with and without depression have been found, even though the subjects with depression were assessed as being clinically remitted [30-32].

In the present study, the subjects in the depression group were assessed as having improved or remitted depression based on referral letters from their psychiatrists rather than on rigorous standards of remission in depression [33,34]. However, the small doses of medication that were being taken and the relatively low SDS scores suggest that subjects in the depression group would likely be categorized as having strictly defined remitted depression.

Taken together, the widespread reduction in CBF observed in the depression group in the present study might reflect the vulnerability of subjects with remitted or almost-remitted depression.

There were three limitations of the present study. The first was that almost all subjects were taking medications at the time of SPECT examination. No significant difference was found in the imipramine equivalent doses; however, other medications (such as antipsychotics, anxiolytics, or hypnotics) and their interactions could affect the CBF. The second limitation was that the depressive states of subjects were not assessed by rigorous standards of remission in depression. The third limitation was the small number of subjects, especially in the depression group. To examine statistical significance with adequate dependability, more studies with a larger number of subjects are necessary.

Regardless of the careful screening to select more homogeneous OSD, subjects of this study still exhibited a range of clinical characteristics and $\mathrm{CBF}$ distribution patterns. Further studies using more subjects from many different clinical aspects are needed to clarify the diversity and pathophysiology of OSD.

\section{Conclusions}

In conclusion, in the present study, no clinical symptomatic difference was observed, and a significant right dominant asymmetry in the temporal and posterior cerebral regions was found in subjects both with monosymptomatic (primary) OSD and with OSD associated with remitted depression. Moreover, $\mathrm{CBF}$ in the depression group was significantly decreased in widespread regions, compared with that in the non-depression group. This phenomenon might reflect medication use, but it is more likely that widespread CBF reduction is a characteristic of remitted depression.

To clarify the pathophysiology of OSD, further studies using more subjects and details are needed.

\section{Abbreviations}

CBF: Cerebral blood flow; DDST: Delusional disorder, somatic type; mCBF: Mean cerebral blood flow; OSD: Oral somatic delusion; rCBF: Regional cerebral blood flow; ROI: Region of interest; SPECT: Single-photon emission computed tomography; HDS-R: Revised hasegawa dementia scale; ${ }^{99 \mathrm{~m}} \mathrm{Tc}$ ECD: Tc-99 m ethylcysteinate dimer; 3DSRT: Three-dimensional stereotactic regions of interest template; SDS: Zung self-rating depression scale.

\section{Competing interests}

The authors declare that they have no competing interests.

\section{Authors' contributions}

MW participated in the design of the study, performed the statistical analysis, and drafted the manuscript. MW, YU, AM, YS, TY, TS, CS, AK, and MT participated in the patients' treatments and collected data. AT performed and assessed SPECT and helped draft the manuscript. AU and TN participated in study design and coordination and helped draft the manuscript. HM and AT conceived of the study, participated in its design and coordination, and helped draft the manuscript. All authors read and approved the final manuscript.

\section{Acknowledgements}

This study was supported in part by a Grant-in-aid for Science Research from the Japan Society for the Promotion of Science (No. 24593141).

\section{Author details}

'Department of Psychosomatic Dentistry, Graduate School of Medical and Dental Sciences, Tokyo Medical and Dental University, 1-5-45 Yushima, Bunkyo-ku, Tokyo 113-8549, Japan. ${ }^{2}$ Psychosomatic Dentistry Clinic, Tokyo Medical and Dental University Dental Hospital, 1-5-45 Yushima, Bunkyo-ku, Tokyo 113-8549, Japan. ${ }^{3}$ Department of Diagnostic Radiology and Oncology, Graduate School of Medical and Dental Sciences, Tokyo Medical and Dental University, 1-5-45 Yushima, Bunkyo-ku, Tokyo 113-8519, Japan. ${ }^{4}$ Department of Psychiatry and Behavioral Sciences, Graduate School of Medical and Dental Sciences, Tokyo Medical and Dental University, 1-5-45 Yushima, Bunkyo-ku, Tokyo 113-8519, Japan.

Received: 20 November 2014 Accepted: 19 February 2015

Published online: 10 March 2015

\section{References}

1. Maeda K, Yamamoto Y, Yasuda M, Ishii K. Delusions of oral parasitosis. Prog Neuropsychopharmacol Biol Psychiatry. 1998;22(1):243-8.

2. Uezato A, Yamamoto N, Kurumaji A, Toriihara A, Umezaki Y, Toyofuku A, et al. Improvement of asymmetrical temporal blood flow in refractory oral somatic delusion after successful electroconvulsive therapy. J ECT. 2012;28(1):50-1.

3. Umezaki Y, Katagiri A, Watanabe M, Takenoshita M, Sakuma T, Sako E, et al. Brain perfusion asymmetry in patients with oral somatic delusions. Eur Arch Psychiatry Clin Neurosci. 2013;263(4):315-23.

4. American Psychiatric Association. Diagnostic and Statistical Manual of Mental Disorders (4 ${ }^{\text {th }}$ ed, text revision). Washington, DC: American Psychiatric Publishing; 1994.

5. Tateno A, Kimura M, Shimoda K, Hada M, Mori T, Suzuki H, et al. The Characteristics of Cenesthopathy in 123I-IMP SPECT: Comparison with Depression. Brain Sci Ment Disord. 2001;12(2):127-32 (in Japanese).

6. Ghaffari-Nejad A, Toofani K. Delusion of oral parasitosis in a patient with major depressive disorder. Arch Iran Med. 2006;9(1):76-7.

7. Hanihara T, Takahashi T, Washizuka S, Ogihara T, Kobayashi M. Delusion of oral parasitosis and thalamic pain syndrome. Psychosomatics. 2009;50(5):534-7.

8. Hayashi H, Oshino S, Ishikawa J, Kawakatsu S, Otani K. Paroxetine treatment of delusional disorder, somatic type. Hum Psychopharmacol. 2004;19(5):351-2. 1p following 352.

9. Narumoto J, Ueda H, Tsuchida H, Yamashita T, Kitabayashi Y, Fukui K. Regional cerebral blood flow changes in a patient with delusional parasitosis before and after successful treatment with risperidone: a case report. Prog Neuropsychopharmacol Biol Psychiatry. 2006;30(4):737-40.

10. Wada T, Kawakatsu S, Komatani A, Okuyama N, Otani K. Possible association between delusional disorder, somatic type and reduced regional cerebral blood flow. Prog Neuropsychopharmacol Biol Psychiatry. 1999;23(2):353-7.

11. Karibe H, Arakawa R, Tateno A, Mizumura S, Okada T, Ishii T, et al. Regional cerebral blood flow in patients with orally localized somatoform pain disorder: a single photon emission computed tomography study. Psychiatry Clin Neurosci. 2010;64(5):476-82. 
12. Newberg AB, Hersh EV, Levin LM, Giannakopoulos H, Secreto SA, Wintering $N A$, et al. Double-blind, placebo-controlled, randomized pilot study of cerebral blood flow patterns employing SPECT imaging in dental postsurgical pain patients with and without pain relief. Clin Ther. 2011;33(12):1894-903.

13. Duschek S, Hellmann N, Merzoug K, del Paso GA R, Werner NS. Cerebral blood flow dynamics during pain processing investigated by functional transcranial Doppler sonography. Pain Med. 2012;13(3):419-26.

14. Matsuda H, Yagishita A, Nakatsuji H, Miyazawa M. [Noninvasive regional cerebral blood flow measurements by 99mTc-HMPAO using only three-head SPECT system]. Kaku Igaku. 1994;31(8):991-4 (in Japanese).

15. Matsuda H, Yagishita A, Tsuji S, Hisada K. A quantitative approach to technetium-99 m ethyl cysteinate dimer: a comparison with technetium99 m hexamethylpropylene amine oxime. Eur J Nucl Med. 1995;22(7):633-7.

16. Friberg L, Andersen AR, Lassen NA, Holm S, Dam M. Retention of 99mTcbicisate in the human brain after intracarotid injection. J Cereb Blood Flow Metab. 1994;14 Suppl 1:S19-27.

17. Lassen NA, Andersen AR, Friberg L, Paulson OB. The retention of [99mTc]-d, I-HM-PAO in the human brain after intracarotid bolus injection: a kinetic analysis. J Cereb Blood Flow Metab. 1988;8(6):S13-22.

18. Kobayashi S, Tateno M, Utsumi K, Takahashi A, Saitoh M, Morii H, et al. Quantitative analysis of brain perfusion SPECT in Alzheimer's disease using a fully automated regional cerebral blood flow quantification software, 3DSRT. J Neurol Sci. 2008;264(1-2):27-33.

19. Takeuchi R, Matsuda H, Yoshioka K, Yonekura Y. Cerebral blood flow SPET in transient global amnesia with automated ROI analysis by 3DSRT. Eur J Nucl Med Mol Imaging. 2004;31(4):578-89.

20. Inagaki A, Inada T, Fujii Y, Yagi K, Yoshio T, Nakamura H, et al. Kouseishinnyaku no Toukakannsann. Tokyo: Seiwa Shoten Publishers; 1999 (in Japanese).

21. Howes OD, Egerton A, Allan V, McGuire P, Stokes P, Kapur S. Mechanisms underlying psychosis and antipsychotic treatment response in schizophrenia: insights from PET and SPECT imaging. Curr Pharm Des. 2009;15(22):2550-9.

22. Monkawa A. [Study on Effects of an Atypical Antipsychotic Agent, Quetiapine, on Regional Cerebral Blood Flow with 99m Tc-ECD SPECT in Drug-naive or Unmedicated Schizophrenic Patients]. J Kanazawa Med Univ. 2007:32(4):192-202. in Japanese.

23. Miller DD, Andreasen NC, O'Leary DS, Rezai K, Watkins GL, Ponto LL, et al. Effect of antipsychotics on regional cerebral blood flow measured with positron emission tomography. Neuropsychopharmacology. 1997;17(4):230-40.

24. Sackeim HA, Prohovnik I, Moeller JR, Brown RP, Apter S, Prudic J, et al. Regional cerebral blood flow in mood disorders. I. Comparison of major depressives and normal controls at rest. Arch Gen Psychiatry. 1990;47(1):60-70.

25. Fountoulakis KN, lacovides A, Gerasimou G, Fotiou F, loannidou C, Bascialla $F$, et al. The relationship of regional cerebral blood flow with subtypes of major depression. Prog Neuropsychopharmacol Biol Psychiatry. 2004;28(3):537-46.

26. Kanaya T, Yonekawa M. Regional cerebral blood flow in depression. Jpn J Psychiatry Neurol. 1990;44(3):571-6.

27. Nagafusa Y, Okamoto N, Sakamoto K, Yamashita F, Kawaguchi A, Higuchi T, et al. Assessment of cerebral blood flow findings using 99mTc-ECD singlephoton emission computed tomography in patients diagnosed with major depressive disorder. J Affect Disord. 2012;140(3):296-9.

28. Rogers MA, Kasai K, Koji M, Fukuda R, Iwanami A, Nakagome K, et al. Executive and prefrontal dysfunction in unipolar depression: a review of neuropsychological and imaging evidence. Neurosci Res. 2004;50(1):1-11.

29. Oda K, Okubo Y, Ishida R, Murata Y, Ohta K, Matsuda T, et al. Regional cerebral blood flow in depressed patients with white matter magnetic resonance hyperintensity. Biol Psychiatry. 2003;53(2):150-6.

30. Liotti M, Mayberg HS, McGinnis S, Brannan SL, Jerabek P. Unmasking disease-specific cerebral blood flow abnormalities: mood challenge in patients with remitted unipolar depression. Am J Psychiatry. 2002;159 (11):1830-40.

31. Navarro V, Gasto C, Lomena F, Mateos JJ, Marcos T, Portella MJ. Normalization of frontal cerebral perfusion in remitted elderly major depression: a 12-month follow-up SPECT study. Neuroimage. 2002;16(3 Pt 1):781-7.

32. Salvadore G, Nugent AC, Lemaitre H, Luckenbaugh DA, Tinsley R, Cannon DM, et al. Prefrontal cortical abnormalities in currently depressed versus currently remitted patients with major depressive disorder. Neuroimage. 2011;54(4):2643-51.

33. Navarro V, Gonzalez A, Guarch J, Penades R, Torra M, Fananas L, et al. Association between symptomatic profile and remission following antidepressant treatment in unipolar major depression. J Affect Disord. 2013;150(2):209-15.

34. Rush AJ, Kraemer HC, Sackeim HA, Fava M, Trivedi MH, Frank E, et al. Report by the ACNP Task Force on response and remission in major depressive disorder. Neuropsychopharmacology. 2006;31(9):1841-53.

\section{Submit your next manuscript to BioMed Central and take full advantage of:}

- Convenient online submission

- Thorough peer review

- No space constraints or color figure charges

- Immediate publication on acceptance

- Inclusion in PubMed, CAS, Scopus and Google Scholar

- Research which is freely available for redistribution

Submit your manuscript at www.biomedcentral.com/submit 